\title{
Characterization Results for the 2013 HTF 3H Evaporator Overhead Samples
}

A. L. Washington, II

December 4, 2013

SRNL-STI-2013-00525, Revision 0 


\section{DISCLAIMER}

This work was prepared under an agreement with and funded by the U.S. Government. Neither the U.S. Government or its employees, nor any of its contractors, subcontractors or their employees, makes any express or implied:

1. warranty or assumes any legal liability for the accuracy, completeness, or for the use or results of such use of any information, product, or process disclosed; or

2. representation that such use or results of such use would not infringe privately owned rights; or

3. endorsement or recommendation of any specifically identified commercial product, process, or service.

Any views and opinions of authors expressed in this work do not necessarily state or reflect those of the United States Government, or its contractors, or subcontractors.

\section{Printed in the United States of America \\ Prepared for U.S. Department of Energy}




\section{Characterization Results for the 2013 HTF 3H Evaporator Overhead Samples}

A. L. Washington, II

December 4, 2013

Prepared for the U.S. Department of Energy under contract number DE-AC09-08SR22470. 


\section{REVIEWS AND APPROVALS}

\section{AUTHORS:}

A. L. Washington, II, Advanced Characterization and Processing

Date

TECHNICAL REVIEW:

S.H. Reboul, Advanced Characterization and Processing Date

APPROVAL:

F. M. Pennebaker, Manager

Date

Advanced Characterization and Processing

S.L. Marra, Manager

Date

Environmental \& Chemical Process Technology Research Programs

D. J. Martin, Manager

Date

Tank Farm/ETP Process Engineering Lead 


\section{EXECUTIVE SUMMARY}

This report tabulates the radiochemical analysis of the $3 \mathrm{H}$ evaporator overhead sample for ${ }^{137} \mathrm{Cs},{ }^{90} \mathrm{Sr}$, and ${ }^{129}$ I to meet the requirements in the Effluent Treatment Project (ETP) Waste Acceptance Criteria (WAC) (rev. 6). This report identifies the sample receipt date, preparation method, and analysis performed in the accumulation of the listed values. All data was found to be within the ETP WAC (rev. 6) specification for the Waste Water Collection Tanks (WWCT). 


\section{TABLE OF CONTENTS}

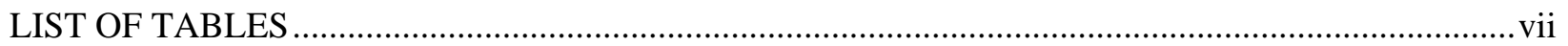

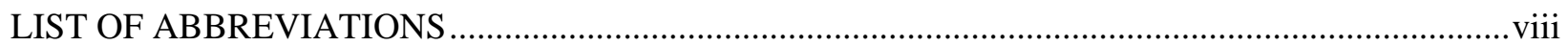

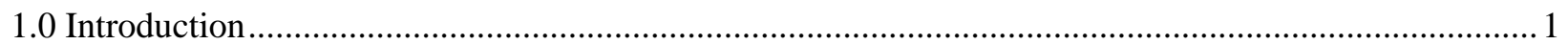

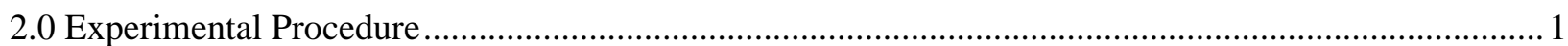

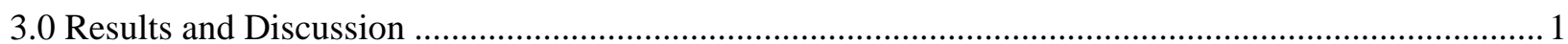

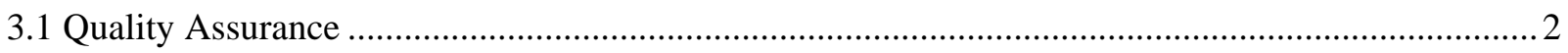

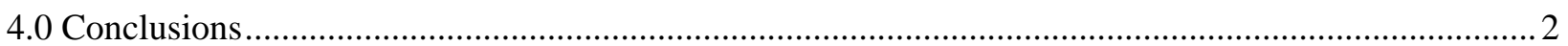

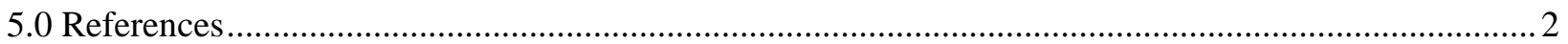


SRNL-STI-2013-00525

Revision 0

\section{LIST OF TABLES}

Table 3-1. Results of Radiochemical Analysis ................................................................................... 1 


\section{LIST OF ABBREVIATIONS}

$\begin{array}{ll}\text { ELN } & \text { Electronic Laboratory Notebook } \\ \text { ETP } & \text { Effluent Treatment Project } \\ \text { SRNL } & \text { Savannah River National Laboratory } \\ \text { WAC } & \text { Waste Acceptance Criteria } \\ \text { WWCT } & \text { Waste Water Collection Tanks }\end{array}$




\subsection{Introduction}

The Tank farm has submitted annual samples from the $3 \mathrm{H}$ evaporator overhead stream on August 22, 2013 for radiochemical characterization to verify compliance with the Effluent Treatment Project (ETP) Waste Acceptance Criteria (WAC) ${ }^{1}$ (rev. 6).

\subsection{Experimental Procedure}

The 3H annual evaporator overhead samples arrived at the Savannah River National laboratory on August 22, 2013. Of these four received samples, there were two samples in glass bottles and two in poly bottles. For this report, a $250 \mathrm{~mL}$ sample aliquot was taken from the poly bottles and transferred to a $500 \mathrm{~mL}$ sample bottle more suitable for transmittal to the Analytical Development Section (ADS). Since these samples were relatively low in activity, no dilution was required prior to submittal for analysis. A blank is normally not used in the radiochemical portion of this analysis and therefore not addressed in this report. Baseline levels of the experiments were confirmed from instrument calibrations.

Three different analytical methods were used by ADS to determine the concentrations of ${ }^{137} \mathrm{Cs}$, ${ }^{90} \mathrm{Sr}$, and ${ }^{129} \mathrm{I}$ in the sample. Gamma spectrometry was used to determine the ${ }^{137} \mathrm{Cs}$ concentration. Radiochemical separation followed by liquid scintillation counting was utilized to determine the ${ }^{90} \mathrm{Sr}$ concentration. Radiochemical separation followed by low energy gamma photon spectroscopy was utilized to determine the ${ }^{129}$ I concentration.

\subsection{Results and Discussion}

The results of the analyses provided in the table below are for a single determination by Analytical Development (AD). For the ${ }^{129} \mathrm{I}$ and ${ }^{90} \mathrm{Sr}$, the concentration fell below the lower limit of detection. In these cases, AD reported the lower limit of detection preceded by “<”.

Table 3-1 provides the measured concentrations of ${ }^{137} \mathrm{Cs}$, ${ }^{129} \mathrm{I}$, and ${ }^{90} \mathrm{Sr}$ in the annual samples. The samples were submitted from the $3 \mathrm{H}$ evaporator overhead, along with the limits given in the current revision of the ETP WAC. ${ }^{1}$ All radionuclide concentrations in the sample were found to be less than the corresponding ETP WAC limits.

Table 3-1. Results of Radiochemical Analysis

\begin{tabular}{|c|c|c||}
\hline Analyte & $\begin{array}{c}\text { 3H Evap } \\
\text { Overheads } \\
\text { (dpm/mL) }\end{array}$ & $\begin{array}{c}\text { WWCT Feed } \\
\text { Acceptance Limits } \\
\text { (dpm/mL) }\end{array}$ \\
\hline${ }^{137} \mathrm{Cs}$ & $2.65 \mathrm{E}+02$ & $3.28 \mathrm{E}+02$ \\
\hline${ }^{90} \mathrm{Sr}$ & $<2.43 \mathrm{E}+00$ & $1.76 \mathrm{E}+02$ \\
\hline${ }^{129} \mathrm{I}$ & $<3.33 \mathrm{E}-02$ & $1.00 \mathrm{E}+00$ \\
\hline
\end{tabular}


The values listed in Table 3-1 are in good concurrence with previous data. In the 2011 sampling report, the concentrations of these radionuclides were $2.26 \mathrm{E}+02,<1.64 \mathrm{E}+01$, and $<6.06 \mathrm{E}-01$ in units of dpm/mL for ${ }^{137} \mathrm{Cs}$, ${ }^{90} \mathrm{Sr}$, and ${ }^{129} \mathrm{I}$, respectively. ${ }^{2}$ The ${ }^{137} \mathrm{Cs}$ concentration has increased about $15 \%$ from the 2011 sampling to the current sample. Additionally, both the ${ }^{90} \mathrm{Sr}$ and ${ }^{129} \mathrm{I}$ concentrations were below the detection limit in both the 2011 and 2013 samples.

\subsection{Quality Assurance}

This report was developed in accordance with the protocols identified in Task Technical and Quality Assurance Plan SRNL-RP-2013-0058. ${ }^{3}$

Requirements for performing reviews of technical reports and the extent of review are established in manual E7 2.60. SRNL documents the extent and type of review using the SRNL Technical Report Design Checklist contained in WSRC-IM-2002-00011, Rev. 2. The data from this experiment is contained in an electronic laboratory notebook (ELN). ${ }^{4}$

\subsection{Conclusions}

The 3H Evaporator Overhead sample was found to be in compliance with the ETP WAC based on the limited radiochemical analysis performed for ${ }^{137} \mathrm{Cs},{ }^{90} \mathrm{Sr}$, and ${ }^{129} \mathrm{I}$. Additionally, the concentrations of the aforementioned radionuclides are in agreement with the previous analysis performed in 2011.

\subsection{References}

\footnotetext{
1 “F/H Effluent Treatment Facility Waste Acceptance Criteria,” X-SD-H-00009, Revision 6, June 2012.

${ }^{2}$ Washington, A.L., "Report on the Analysis of WAC Samples from Evaporator Overheads for 2011,” SRNL-STI-2011-00660, March 2012.

${ }^{3}$ Washington, A.L.," Task Technical and Quality Assurance Plan for 2013 Evaporator Overhead Sample Analysis,” SRNL-RP-2013-00528, Revision 0, August 2013.

${ }^{4}$ Electronic Laboratory Notebook “3H Evaporator Overhead Analysis for 2013,” E5690-0007701.
} 


\section{Distribution:}

S. L. Marra, 773-A

T. B. Brown, 773-A

D. R. Click, 999-W

S. D. Fink, 773-A

C. C. Herman, 773-A

E. N. Hoffman, 999-W

F. M. Pennebaker, 773-42A

W. R. Wilmarth, 773-A

Records Administration (EDWS)

P. R. Jackson, DOE-SR, 703-46A

K. H. Subramanian, 241-156H

W. A. Drown, 773-41

D. J. Martin, 241-152H

A. W. Wiggins, $241-168 \mathrm{H}$

H. Bui, 241-152H

D. E. Morgan, 241-168H 